\title{
TINGKAT CEMARAN LOGAM BERAT TIMBAL (Pb) PADA TUTUT (Filopaludina javanica) DI WADUK CIRATA, JAWA BARAT
}

\author{
Nisha Nurfadhilla ${ }^{1}$, Isni Nurruhwati ${ }^{1}$, Sunardi ${ }^{2}$, dan Zahidah ${ }^{\mathbf{1}}$ \\ ${ }^{1}$ Program Studi Perikanan, Fakultas Perikanan dan Ilmu Kelautan, Universitas Padjadjaran \\ Jl. Raya Bandung-Sumedang KM. 21 Jatinangor, 456363 \\ ${ }^{2}$ Program Studi Biologi, Fakultas Matematika dan Ilmu Pengetahuan Alam, Universitas Padjadjaran \\ Jl. Raya Bandung-Sumedang KM. 21 Jatinangor, 456363 \\ E-mail: nishanurfadhilla4@gmail.com
}

\begin{abstract}
ABSTRAK
Waduk Cirata mengalami penurunan kualitas perairan, penyebab menurunnya kualitas perairan tersebut adalah masuknya limbah yang berasal dari limbah pertanian, domestik, industri, transportasi, peternakan dan perikanan. Terdapat jenis limbah yang masuk ke perairan mengandung logam berat timbal $(\mathrm{Pb})$ seperti limbah industri, limbah transportasi dan limbah pertanian. Timbal berbahaya bagi lingkungan perairan dan organisme, yang banyak tersebar di Waduk Cirata seperti makrozoobenthos jenis tutut (Filopaludina javanica). Tutut dimanfaatkan sebagai sumber bahan pangan bagi warga di sekitar Waduk Cirata. Tujuan penelitian ini adalah untuk mengetahui tingkat pencemaran logam berat timbal $(\mathrm{Pb})$ pada tutut di Waduk Cirata Jawa Barat. Penelitian dilakukan pada 18 September - 30 November 2018. Metode yang dilakukan adalah metode survey dan penentuan lokasi pengambilan sampel dengan purpose sampling. Pengambilan sampel air, substrat dan biota tutut dilakukan di tiga stasiun pengamatan. Analisis timbal $(\mathrm{Pb})$ dilakukan pada sampel air, substrat, dan biota tutut dengan menggunakan Atomic Absorption Spectrophotometer (AAS). Hasil analisis menunjukkan bahwa Konsentrasi timbal $(\mathrm{Pb})$ pada air yaitu $0,0307 \mathrm{mg} / \mathrm{L}$, substrat berkisar antara $3,26-7,32 \mathrm{mg} / \mathrm{kg}$ dan tutut sebesar $0,05 \mathrm{mg} / \mathrm{kg}$ sedangkan nilai IFK 0 -s sebesar 0,0106 dan nilai IFK IF-a $_{0}$ sebesar 1,6286. Nilai konsentrasi yang dihasilkan pada air sudah melebihi ambang batas baku mutu sehingga perairan dapat dikategorikan sudah tercemar sedangkan nilai konsentrasi yang dihasilkan pada substrat dan tutut belum melebihi ambang batas baku mutu sehingga dikategorikan belum tercemar.
\end{abstract}

Kata kunci: Makrozoobenthos; Pencemaran; Tutut; Timbal; Waduk Cirata.

\section{LEVEL CONTAMINATION OF HEAVY METAL POLLUTION OF LEAD (Pb) ON SNAIL (Filopaludina javanica) IN RESERVOIR CIRATA WEST JAVA}

\begin{abstract}
Cirata Reservoir has decreased water quality, the cause of declining water quality is the inclusion of waste derived from agricultural waste, domestic, industrial, transportation, livestock and fisheries. There are types of wastes that enter the water containing lead heavy metals $(\mathrm{Pb})$ such as industrial waste, transportation waste and agricultural waste. The lead is harmful to aquatic environments and organisms, which are widely dispersed in the Cirata reservoir such as the Tutut-type Macrozoobenthos (Filopaludina javanica). Tutut is used as a source of foodstuffs for residents around the Cirata Reservoir. The purpose of this research is to determine the level of pollution of the lead heavy Metals $(\mathrm{Pb})$ in Tutut in West Java's Cirata Reservoir. The study was conducted on 18 September - 30 November 2018. The method is survey method and determination of sampling location with purpose sampling. The water sampling, substrate and the tutut plant were carried out at three observation stations. Lead analysis (PB) is performed on water samples, substrates, and Tutut biota using the Atomic Absorption Spectrophotometer (AAS). The results of the analysis showed that the lead concentration $(\mathrm{Pb})$ in the water is 0.0307 $\mathrm{mg} / \mathrm{L}$, the substrate ranged from $3.26-7.32 \mathrm{mg} / \mathrm{kg}$ and the amount of $0.05 \mathrm{mg} / \mathrm{kg}$ while the IFK0-s value is 0.0106 and IFK0a value of 1.6286 . The value of the concentration generated in water exceeds the quality of the standard threshold so that the water can be categorized as contaminated while the value of the concentration generated on the substrate and Tutut has not exceeded the quality standard threshold so it is categorized unpolluted.
\end{abstract}

Key words: Macrozoobenthos; Pollution; Tutut; Lead; Cirata Reservoir.

\section{PENDAHULUAN}

Waduk Cirata merupakan salah satu dari 3 (tiga) waduk di Daerah Aliran Sungai (DAS) Citarum, Provinsi Jawa Barat. Waduk Cirata adalah waduk serbaguna yang terletak di 3 (tiga) kabupaten yaitu: Purwakarta, Cianjur, dan Bandung Barat Provinsi Jawa Barat (Saputra, 2009). Waduk Cirata merupakan ekosistem perairan yang memiliki banyak potensi seperti Pembangkit Tenaga Listrik, budidaya ikan, sumber pengairan, tempat rekreasi bagi masyarakat, dan sarana perhubungan. Waduk Cirata telah mengalami penurunan daya guna akibat pengaruh lingkungan yang ditimbulkan terlalu berat seperti banyaknya limbah organik dan anorganik yang dibuang langsung ke Waduk Cirata, penurunan daya guna ini dapat berupa penurunan kualitas perairan yang bersifat fisik, kimiawi maupun biologis (Saputra, 2009).

Penurunan kualitas perairan ini disebabkan karena secara langsung waduk tersebut menerima berbagai masukan limbah yang dibuang dari pabrik tekstil, pelapisan logam, makanan, minuman, kertas dan berbagai macam limbah yang berasal dari buangan limbah domestik, dan dari lahan pertanian (Saputra, 2009). Waduk Cirata merupakan daerah yang menerima berbagai limbah organik dan anorganik. Hal ini menjadi salah satu faktor yang 
mempengaruhi kesuburan perairan dan juga merupakan faktor terjadi pencemaran yang berpengaruh pada kelestarian keragaman hayati di perairan Waduk Cirata.

Limbah organik berasal dari makhluk hidup contohnya yaitu ikan yang mati dan dedaunan yang sudah mati sedangkan limbah anorganik berasal dari zat kimia atau industri contohnya yaitu logam berat seperti timbal $(\mathrm{Pb})$, kadmium $(\mathrm{Cd})$ dan besi $(\mathrm{Fe})$. Oktavianus dan Salami (2005) mengungkapkan bahwa timbal $(\mathrm{Pb})$ berasal dari industri-industri seperti pabrik baterai, amunisi, kawat, logam campuran, dan cat. Salah satu kontaminan atau limbah anorganik yang masuk ke Waduk Cirata adalah logam berat (Wicaksono, 2016). Logam berat merupakan zat yang berbahaya dan beracun jika jumlahnya melebihi ambang batas (Nurhayati, 2019). Logam berat merupakan unsur yang cukup berbahaya bagi lingkungan perairan, sifat logam berat mudah mengendap pada sedimen dan mempunyai waktu endapan hingga ribuan tahun lamanya (Saputra, 2009).

Logam berat dibagi menjadi dua jenis yaitu: logam berat esensial dan logam berat non esensial. Logam berat esensial adalah logam dalam jumlah tertentu yang sangat dibutuhkan oleh organisme, akan tetapi logam tersebut bisa menimbulkan efek racun jika dalam jumlah yang berlebihan, contohnya yaitu: $\mathrm{Zn}, \mathrm{Cu}, \mathrm{Fe}, \mathrm{Mn}$ dan lain lain sedangkan logam non esensial adalah logam yang keberadaannya dalam tubuh masih belum diketahui manfaatnya bahkan bersifat racun, contohnya yaitu: $\mathrm{Hg}, \mathrm{Cd}, \mathrm{Pb}, \mathrm{Cr}$ dan lain lain (Irhamni, 2017). Menurut Priyanto et al., (2008) banyak ditemukan logam berat $\mathrm{Hg}, \mathrm{Pb}, \mathrm{Cd}$ dan $\mathrm{Cu}$ di Waduk Cirata hal ini disebabkan karena banyaknya limbah dari kegiatan industri di sekitar sungai yang masuk ke Waduk Cirata.

Logam berat timbal $(\mathrm{Pb})$ di Waduk Cirata banyak dihasilkan dari lalu lintas kapal/perahu, limbah buangan industri, dan limbah domestik (Wicaksono, 2016). Kapal/ perahu memiliki peranan dalam menyumbangkan logam berat timbal $(\mathrm{Pb})$ hal ini karena kapal/ perahu menggunakan bahan bakar minyak, bahan bakar minyak tersebut diberi tambahan tetraethyl yang mengandung timbal $(\mathrm{Pb})$ untuk meningkatkan kualitas dari bahan bakar tersebut.

Salah satu komunitas biologis atau organisme yang merasakan langsung pengaruh bahan pencemar tersebut adalah makrozoobentos, makrozoobentos adalah organisme yang hidup di dasar perairan (Dhahiyat, 2011). Sifat makrozoobentos yang cenderung bersifat menetap dan tidak mampu menghindari bahan-bahan pencemar juga memberikan kontribusi tersendiri bagi kemungkinan terjadinya akumulasi logam berat pada organisme makrozoobentos. Hal ini menjadikan makrozoobentos sebagai salah satu kelompok organisme yang sering digunakan sebagai indikator pencemaran lingkungan dan indikator pencemaran logam berat. Salah satu makrozoobenthos yang tersebar di Waduk Cirata yaitu tutut atau yang dikenal dengan keong air tawar.

Tutut merupakan salah satu makozoobenthos yang dikonsumsi oleh masyarakat, tutut juga mudah ditemui dan harganya ekonomis. Tutut memiliki peluang yang besar untuk terkontaminasi timbal $(\mathrm{Pb})$ karena termasuk makrozoobentos yang bersifat menetap, apabila tutut yang tercemar timbal $(\mathrm{Pb})$ dikonsumsi oleh masyarakat dapat menyebabkan terganggunya kesehatan manusia. Oleh karena itu, tujuan penelitian ini adalah untuk menentukan tingkat pencemaran logam berat timbal $(\mathrm{Pb})$ pada tutut di Waduk Cirata Jawa Barat dengan membandingkan kandungan logam berat timbal $(\mathrm{Pb})$ yang dapat ditolerir seperti yang direkomendasikan Peraturan Pemerintah No. 82 tahun 2001, IACD/CEDA (International Association of Draging Companies/ Central Dreging Association) (1999) dan batas maksimum logam berat dalam pangan menurut SNI No.7387 tahun 2009.

\section{METODE}

Pengambilan sampel berupa air, substrat dan tutut (Filopaludina javanica). Pengambilan sampel dilaksanakan pada 18 September 2018 berlokasi di Waduk Cirata, Jawa Barat. Lokasi stasiun pengambilan sampel ditentukan 3 stasiun dengan metode purposive sampling, pada masing-masing stasiun dilakukan 3 kali ulangan. Penelitian dilakukan dengan survei. Sampel air diambil pada lapisan permukaan kedalaman 0,2 $\mathrm{m}$ dan dimasukkan ke dalam botol kaca (volume $100 \mathrm{ml}$ ), sampel substrat diambil dari dasar perairan dan dimasukkan ke dalam plastik, sampel tutut diambil menggunakan jala surber dan dimasukkan ke dalam plastik. Setelah itu sampel air, substrat dan tutut dimasukkan ke dalam cool box selama transportasi ke laboratorium. Lokasi masingmasing stasiun pengambilan sampel memiliki karakteristik yang berbeda-beda. Lokasi pengambilan sampel disajikan pada Gambar 1. Keterangan lokasi, posisi geografis, deskripsi lokasi dan foto lokasi dapat dilihat pada Tabel 1 .

Analisis laboratorium untuk pengamatan konsentrasi logam timbal $(\mathrm{Pb})$ pada tutut,air dan substrat dilakukan di laboratorium Pusat Penelitian dan Pengembangan Sumber Daya Alam dan Lingkungan (PPSDAL) Universitas Padjadjaran pada 20 September 2018 - 30 November 2018. Metode analisis air, substrat dan tutut yang digunakan pada penelitian ini disajikan pada Tabel 2 .

Selajutnya data hasil laboratorium dianalisis secara deskriptif komparatif. Data yang diperoleh disajikan dalam bentuk tabel atau grafik untuk kemudian dibandingkan hasil pengukurannya antar stasiun yang diamati dan dibandingkan dengan kriteria baku mutu air berdasarkan Peraturan Pemerintah No. 82 Tahun 2001 (Tabel 3) dan IACD/CEDA (1999) untuk sedimen dan batas maksimum logam berat dalam pangan menurut SNI No. 7387 Tahun 2009. 


\section{PETA LOKASI PENELITIAN WADUK CIRATA, JAWA BARAT}

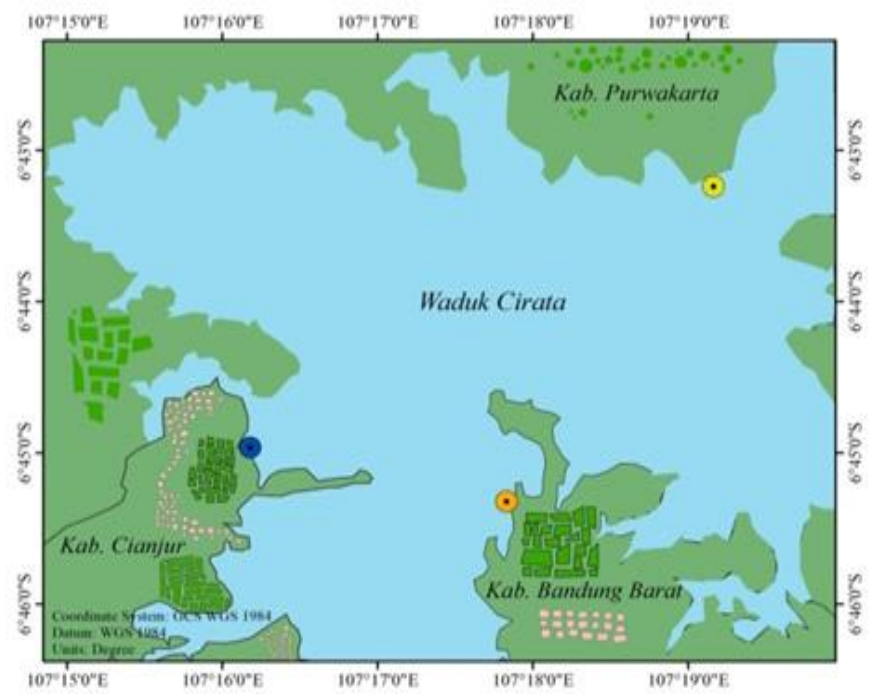

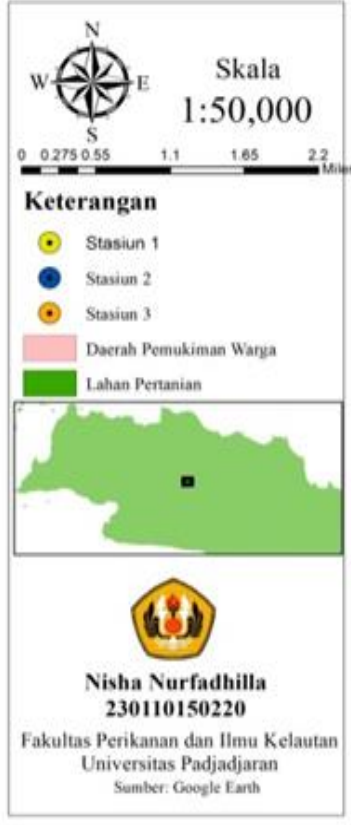

Gambar 1 Titik lokasi pengambilan sampel di Waduk Cirata.

(Sumber : www.googlemap.com/peta/cirata )

Tabel 1 Deskripsi lokasi pengambilan sampel

\begin{tabular}{lll}
\hline No & Nama lokasi & \multicolumn{1}{c}{ Posisi geografis } \\
& & \\
& & $107^{\circ} 17,929^{\prime}$ LS dan $06^{\circ}$ \\
& & $43,181^{\prime}$ BT terletak di \\
& Stasiun 1 & wilayah Purwakarta area \\
& Tegal datar.
\end{tabular}

$107^{\circ} 15,975^{\prime}$ LS dan $06^{\circ}$ 43,589'BT

2 Stasiun 2 terletak di wilayah Cianjur area Muara Sungai Cibalagung, Jangari.

$107^{\circ} 19,570^{\prime} \mathrm{LS}$ dan $06^{\circ}$ 44,608' BT Terdapat banyak eceng 3 Stasiun 3 terletak di wilayah Bandun gondok, dan pemukiman Barat area Muara Sungai warga. Cilangkap, Cibogo.
Terdapat eceng gondok, karamba jarig apung menjadi jalur lalu lintas

kapal pengangkut pakan ikan, persawahan dan pemukiman warga.

Terdapat eceng gondok dan karamba jaring apung, perkebunan masyarakat, persawahan dan peternakan sapi.
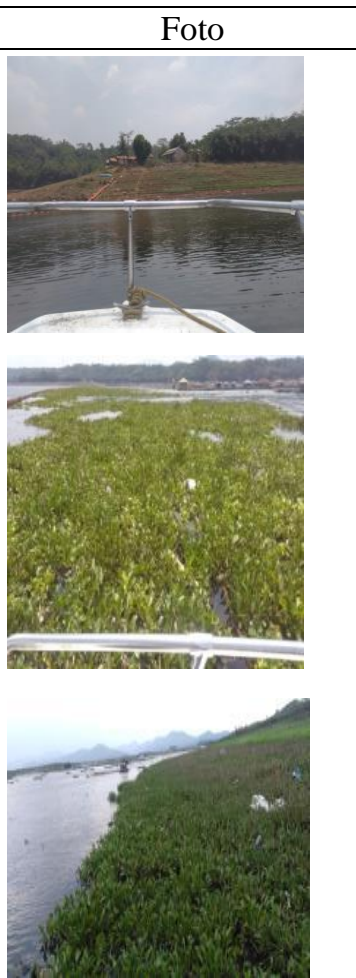

Tabel 2 Parameter yang diamati dan metodenya.

\begin{tabular}{llll}
\hline No & Parameter yang diamati & Metode/alat & Keterangan \\
\hline 1 & Pb Air & SNI 6989.8-2009 & Ex situ \\
2 & Pb Substrat & SNI 06-6992.3-2004 & Ex situ \\
3 & Pb Tutut & SNI 7387-2009 & Ex situ \\
4 & Oksigen terlarut & DO meter & In situ \\
5 & Suhu & Termometer & In situ \\
6 & $\mathrm{pH}$ & pH meter & In situ \\
\hline
\end{tabular}


Tabel 3 Nilai baku mutu kualitas air berdasarkan Peraturan Pemerintah No. 82 Tahun 2001.

\begin{tabular}{lllllll}
\hline No & Parameter & Satuan & Kelas I & Kelas II & Kelas III & Kelas IV \\
\hline 1. & Suhu & ${ }^{\circ} \mathrm{C}$ & Deviasi 3 & Deviasi 3 & Deviasi 3 & Deviasi 5 \\
2. & Oksigen terlarut (DO) & $\mathrm{mg} / \mathrm{L}$ & $>6$ & $>4$ & $>3$ & $>0$ \\
3. & $\mathrm{pH}$ & - & $6,0-9,0$ & $6,0-9,0$ & $6,0-9,0$ & $5,0-9,0$ \\
4. & Timbal $(\mathrm{Pb})$ & $\mathrm{Mg} / \mathrm{L}$ & 0,03 & 0,03 & 0,03 & 1 \\
\hline
\end{tabular}

Tabel 3 menunjukkan bahwa berdasarkan Peraturan Pemerintah No. 82 Tahun 2001, parameter pada kategori Kelas 1 dapat digunakan untuk air baku air minum, dan atau peruntukan lain yang memperssyaratkan mutu air yang sama dengan kegunaan tersebut. Sementara itu, pada kategori Kelas II menunjukkan bahwa air dapat digunakan untuk prasarana/saran rekreasi air, pembudidayaan ikan air tawar, peternakan, air untuk mengairi pertanaman, dan atau peruntukan lain yang mempersyaratkan mutu air yang sama dengan kegunaan tersebut. Selanjutnya, air pada kategori Kelas III dapat digunakan untuk pembudidayaan ikan air tawar, peternakan, air untuk mengairi pertanaman, dan atau peruntukan lain yang mempersyaratkan mutu air yang sama dengan kegunaan tersebut. Terakhir pada kategori Kelas IV, air dapat digunakan unttuk mengairi pertanaman dan atau peruntukan lain yang mempersyaratkan mutu air yang sama dengan kegunaan tersebut.

\section{Indeks Faktor Konsentrasi}

Kemampuan biota air untuk mengakumulasi timbal $(\mathrm{Pb})$ dapat dilihat dari indeks faktor konsentrasi timbal $(\mathrm{Pb})$ di dalam daging tutut lalu dibandingkan dengan konsentrasi timbal $(\mathrm{Pb})$ di substrat atau di air (Johnston, 1976).

$$
\text { IFK }=\frac{[\mathrm{L}] \text { Daging } \text { Tutut }}{[L] \text { substrat atau air }}
$$

Keterangan :

IFK = Indeks Faktor Konsentrasi

[L] Daging Tutut = Konsentrasi Pb dalam daging Tutut (mg/kg atau ppm)

[L] Substrat/ air = Konsentrasi Pb dalam substrat/air (ppm)

Nilai IFK dibagi menjadi 3 kategori, yaitu sebagai berikut :

IFK $\geq 1000=$ Kategori sifat akumulatif tinggi

$100 \leq$ IFK $\leq 1000$ = Kategori sifat akumulatif sedang
IFK $<100=$ Kategori sifat akumulatif rendah

\section{HASIL DAN PEMBAHASAN}

\section{Konsentrasi Timbal (Pb) dalam Air}

Konsentrasi timbal $(\mathrm{Pb})$ dalam air pada 3 stasiun pengamatan di Waduk Cirata menunjukkan nilai rata-rata sebesar $0,0307 \mathrm{mg} / \mathrm{L}$. Hasil ini sudah melebihi baku mutu air kelas III untuk pembudidayaan ikan air tawar, peternakan, air untuk mengairi pertanaman. menurut Peraturan Pemerintah No. 82 Tahun 2001 yaitu sebesar 0,03 mg/L, sehingga dapat disimpulkan bahwa Waduk Cirata telah tercemar karena konsentrasi timbal $(\mathrm{Pb})$ telah melewati ambang batas baku mutu kelas III sehingga perlu kehati-hatian penggunaan untuk kegiatan pembudidayaan ikan air tawar, peternakan, air untuk mengairi pertanaman, dan atau peruntukan lain yang memperisyaratkan mutu air yang sama dengan kegunaan tersebut. Tinggi rendahnya konsentrasi timbal $(\mathrm{Pb})$ disebabkan oleh jumlah masukan limbah timbal $(\mathrm{Pb})$ ke perairan (Pratiwi, 2018). Semakin besar limbah timbal (Pb) yang masuk ke dalam suatu perairan maka semakin besar konsentrasi timbal $(\mathrm{Pb})$ di perairan tersebut (Effendi, 2003).

Gambar 2 menunjukkan konsentrasi timbal (Pb) dalam air pada masing-masing stasiun pengamatan, hasil pengukuran di stasiun 1 menunjukkan nilai timbal $(\mathrm{Pb})$ sebesar $0,0307 \mathrm{mg} / \mathrm{L}$. Menurut PP No.82 Tahun 2001 bahwa kandungan $\mathrm{Pb}$ di stasiun 1 sudah melampaui baku mutu kelas III yaitu sebesar $0,03 \mathrm{mg} / \mathrm{L}$. Hal ini disebabkan karena letak stasiun 1 yang berdekatan dengan persawahan dan pemukiman warga, selain itu terdapat juga karamba jaring apung sehingga banyak kapal yang membawa pakan ikan sering melewati stasiun ini. Fluktuasi konsentrasi logam berat dapat dipengaruhi oleh masuknya buangan yang mengandung logam berat seperti limbah industri, limbah domestik dan limbah pertanian (Darmono, 1995).

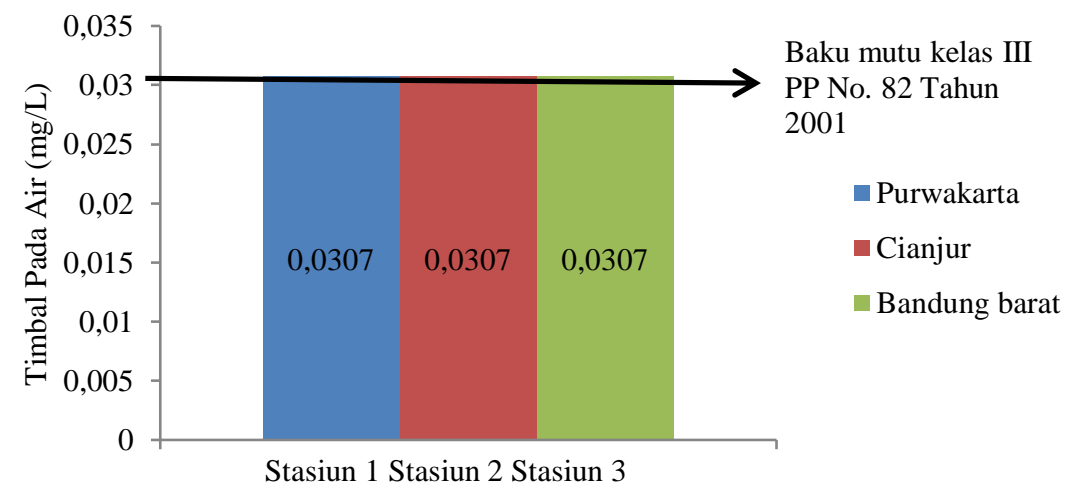

Gambar 2 Konsentrasi timbal $(\mathrm{Pb})$ rata-rata dalam air di tiap stasiun pengamatan. 
Nilai rata-rata pada stasiun 2 yaitu sebesar 0,0307 mg/L. Menurut PP No. 82 Tahun 2001 bahwa kandungan $\mathrm{Pb}$ di stasiun 2 sudah melewati baku mutu kelas III yaitu sebesar $0,03 \mathrm{mg} / \mathrm{L}$. Stasiun 2 merupakan kawasan padat karamba jaring apung maka dari itu banyak kapal yang berada di stasiun ini, selain itu terdapat perkebunan masyarakat, persawahan dan peternakan sapi. Penggunaan motor kapal pada alat transportasi membutuhkan bahan bakar minyak, bahan bakar minyak mendapat tambahan tetraethyl yang mengandung timbal $(\mathrm{Pb})$ untuk meningkatkan kualitas dari bahan bakar tersebut, sehingga hal ini dapat menghasilkan buangan limbah yang menyebabkan kadar timbal $(\mathrm{Pb})$ di perairan menjadi tinggi (Hutagaol, 2012).

Hasil pengukuran di stasiun 3 yaitu sebesar 0,0307 mg/L. Menurut PP No. 82 Tahun 2001 bahwa kandungan $\mathrm{Pb}$ di stasiun 3 sudah melewati baku mutu kelas III yaitu sebesar $0,03 \mathrm{mg} / \mathrm{L}$. Pemukiman warga di stasiun 3 lebih banyak dibandingkan dengan stasiun 1 dan stasiun 2, warga juga melakukan aktifitas rumah tangga yang menghasilkan limbah domestik di stasiun ini, selain itu ada karamba jaring apung milik warga yang berada di stasiun 3 sehingga banyak kapal yang melakukan aktifitasnya di stasiun ini. Cairan limbah rumah tangga dan aliran air perkotaan cukup besar menyumbangkan logam timbal $(\mathrm{Pb})$ ke perairan (Connel \& Miller, 1995).

Konsentrasi timbal $(\mathrm{Pb})$ pada stasiun 1 di Purwakarta, stasiun 2 di Cianjur dan stasiun 3 di Bandung Barat memiliki konsentrasi yang sama yaitu sebesar $0.0307 \mathrm{mg} / \mathrm{L}$, hal ini terjadi karena 3 stasiun pengamatan merupakan jalur lalu lintas kapal pengangkut pakan untuk ikan di karamba jaring apung. Hal ini sesuai dengan karakteristik stasiun 1, 2 dan 3 yang menjadi jalur lalu lintas kapal.

Logam berat timbal $(\mathrm{Pb})$ di Waduk Cirata banyak dihasilkan dari lalu lintas kapal/perahu, limbah buangan industri dan limbah rumah tangga yang mengalir melalui aliran air sungai yang masuk ke dalam waduk. Terdapat pabrik karet dan pabrik keramik di sekitar stasiun 1, 2 dan 3 selain pabrik, ada peternakan sapi dan juga perkebunan warga yang sering membuang limbahnya langsung ke Waduk Cirata hal ini sesuai dengan pernyataan dari Saputra (2009). Peningkatan kadartimbal (Pb) di badan perairan bersumber dari aktifitas manusia berupa emisi gas buang kendaraan bermotor dan limbah industri (Hidayah et al., 2012).

\section{Konsentrasi Timbal (Pb) dalam Substrat}

Konsentrasi timbal $(\mathrm{Pb})$ dalam substrat pada stasiun pengamatan di Waduk Cirata menunjukkan nilai antara $3,26 \mathrm{mg} / \mathrm{kg}-7,32 \mathrm{mg} / \mathrm{kg}$. Menurut IACD/CEDA (International Association of Draging Companies/Central Dreging Association) (1999) bahwa nilai baku mutu logam berat $85 \mathrm{mg} / \mathrm{kg}-1000$ $\mathrm{mg} / \mathrm{kg}$. Selain itu, menurut Rochyatun et al. (2006) baku mutu logam berat dalam lumpur atau sedimen di Indonesia belum ditetapkan, padahal senyawasenyawa logam berat lebih banyak terakumulasi dalam sedimen karena proses pengendapan. Gambar 3 konsentrasi Timbal $(\mathrm{Pb})$ dalam substrat saat penelitian.

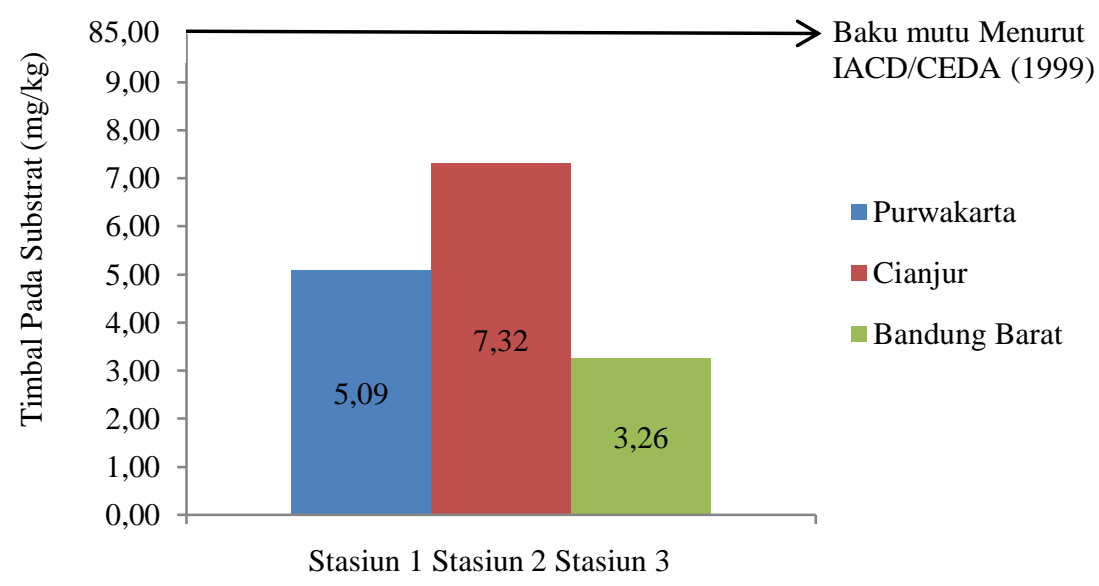

Gambar 3 Konsentrasi timbal $(\mathrm{Pb})$ dalam Substrat di tiap stasiun berkisar antar 3,26 - 7,32 mg/kg.

Konsentrasi timbal $(\mathrm{Pb})$ tertinggi yaitu di stasiun 2 sebesar 7,32 mg/kg. Hal ini disebabkan oleh karakteristik wilayah stasiun 2 yang merupakan zona tengah dan terdapat banyak karamba jaring apung sehingga aktifitas lalu lintas pemberian pakan ikan juga lebih banyak. Aktifitas tersebut menjadi sumber meningkatnya kandungan timbal pada perairan. Hal tersebut sesuai dengan pernyataan Wicaksono (2016) yang mengemukakan bahwa bagian tengah Waduk Cirata merupakan pusat budidaya ikan dengan sistem Budidaya Karamba Jaring Apung. Masuknya logam berat di stasiun 2 berasal dari banyaknya kapal melakukan aktifitas pemberian pakan ikan. Hal tersebut menyebabkan banyak timbal $(\mathrm{Pb})$ yang mengendap.

Konsentrasi timbal $(\mathrm{Pb})$ dengan nilai terendah yaitu ada di stasiun 3 sebesar 3,26 mg/kg, karamba jaring apung yang terdapat di stasiun 3 tidak sebanyak di stasiun 2 sehingga kapal yang melewati stasiun 3 juga sedikit. Hasilnya yaitu konsentrasi timbal $(\mathrm{Pb})$ substrat masih tergolong rendah dan belum melebihi baku mutu menurut IACD/CEDA (1999). Kandungan logam timbal pada air dan sedimen merupakan satu kesatuan dalam perairan logam timbal yang terlarut 
dalam air. Hal tersebut dapat berikatan dengan liganligan dalam air dan membentuk senyawa yang lebih kompleks. Senyawa-senyawa yang kompleks tersebut akan mengendap ke dasar sedimen sehingga konsentrasi logam berat pada air akan berkurang sedangkan konsentrasi logam berat dalam sedimen menjadi lebih besar (Wicaksono, 2016). Selain itu faktor lamanya akumulasi waktu timbal $(\mathrm{Pb})$ pada sedimen tidak akan berkurang dan cenderung akan meningkat.
Konsentrasi Timbal $\quad$ (Pb) dalam Tutut
(Filopaludina javanica)
Konsentrasi rata-rata timbal $(\mathrm{Pb})$ dalam tutut menunjukan hasil sebesar $0,05 \mathrm{mg} / \mathrm{kg}$ sedangkan menurut SNI No. 7387 Tahun 2009 mengenai batas maksimum logam berat dalam pangan, menyebutkan bahwa kadar logam berat timbal $(\mathrm{Pb})$ yang diperbolehkan dalam tubuh biota air yaitu sebesar 0,3 $\mathrm{mg} / \mathrm{kg}$. Konsentrasi rata-rata timbal $(\mathrm{Pb})$ dalam tutut saat penelitian di 4 stasiun (Gambar 4).

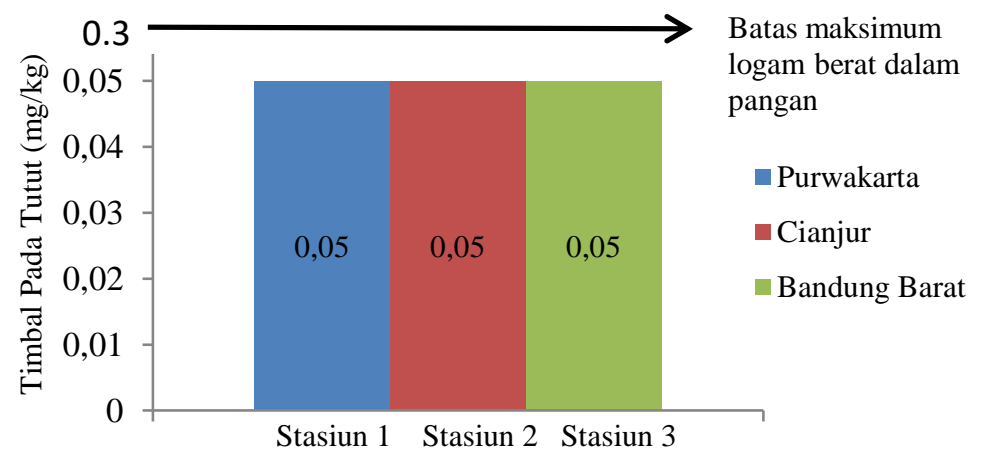

Gambar 4 Konsentrasi rata-rata timbal dalam tutut di tiap stasiun sebesar 0,05 mg/kg.

Gambar 4 menunjukan konsentrasi timbal $(\mathrm{Pb})$ yang sama pada stasiun 1, 2 dan 3 yaitu sebesar 0,05 $\mathrm{mg} / \mathrm{kg}$ sehingga dapat disimpulkan tutut yang berasal dari 3 stasiun tersebut tidak tercemar karena belum melebihi batas maksimum logam berat dalam pangan menurut SNI No. 7387 tahun 2009. Rendahnya kandungan logam berat timbal $(\mathrm{Pb})$ pada tutut ini mengalami penurunan dari penelitian sebelumnya tentang kandungan logam berat timbal $(\mathrm{Pb})$ pada makrozoobenthos di Waduk Cirata tahun 2016. Hasil penelitian tersebut menunjukkan bahwa nilai logam berat timbal memiliki kisaran 0,78 - 3,19 mg/kg. Menurunnya kandungan logam berat timbal $(\mathrm{Pb})$ ini diduga karena adanya upaya pengendalian pencemaran logam berat seperti aturan yang diperketat untuk pabrik agar tidak membuang limbah secara langsung dan aturan pengawasan juga ditambah sehingga kandungan logam berat timbal $(\mathrm{Pb})$ di Waduk Cirata menurun. Hasil pengukuran tersebut menunjukan bahwa konsentrasi Timbal $(\mathrm{Pb})$ dalam tutut di Waduk Cirata belum melebihi batas baku mutu sehingga masih aman untuk di konsumsi.

\section{Indeks Faktor Konsentrasi}

Nilai indeks Faktor Konsentrasi (IFK) yang di peroleh pada penelitian ini terdiri dari dua nilai IFK, yaitu IFK organisme - substrat $\left(\mathrm{IFK}_{0-\mathrm{s}}\right)$ yang berarti nilai perbandingan antara konsentrasi logam yang diserap ke dalam jaringan tutut dengan konsentrasi timbal $(\mathrm{Pb})$ dalam substrat dan IFK organisme - air ( $\mathrm{IFK}_{0-\mathrm{a}}$ ) yaitu nilai perbandingan konsentrasi timbal $(\mathrm{Pb})$ yang diserap ke dalam jaringan tutut dengan konsentrasi timbal $(\mathrm{Pb})$ dalam air. Nilai $\left(\mathrm{IFK}_{0-\mathrm{s}}\right)$ tertinggi ada di stasiun 3 sedangkan nilai $\left(\mathrm{IFK}_{0-\mathrm{s}}\right)$ yaitu stasiun 1, nilai (IFK 0 -a) hasilnya sama (Tabel 4).

Perhitungan nilai IFK pada Tabel 4 menunjukkan bahwa $\left(\mathrm{IFK}_{0-\mathrm{s}}\right)$ tutut dari ketiga titik stasiun penelitian menunujukkan tutut yang berada di Stasiun 3 memiliki kemampuan akumulasi timbal $(\mathrm{Pb})$ yang lebih tinggi, hal ini disebabkan karena Stasiun 3 memiliki konsentrasi timbal $(\mathrm{Pb})$ dengan nilai terendah yaitu sebesar $3,26 \mathrm{mg} / \mathrm{kg}$ penyebab lainnya disebabkan oleh konsentrasi timbal $(\mathrm{Pb})$ dalam tutut sebesar $0,05 \mathrm{mg} / \mathrm{kg}$ sehingga kemampuan akumulasi timbalnya tinggi. Hal ini sesuai dengan penyataan dari Hidayah et al., (2014) yang menyatakan semakin tinggi nilai BCF atau IFK pada suatu organisme menunjukkan semakin tinggi organisme tersebut mengakumulasi logam berat. Nilai $\mathrm{IFK}_{0-\mathrm{a}}$ tutut yaitu sebesar 1,63 nilai ini sama di setiap stasiun pengamatan hal ini terjadi karena konsentrasi timbal $\mathrm{Pb})$ dalam air dan dalam tutut hasilnya sama.

Tabel 4. Nilai indeks faktor konsentrasi (IFK) pada stasiun penelitian.

\begin{tabular}{|c|c|c|c|c|c|}
\hline \multirow{2}{*}{$\begin{array}{c}\text { Lokasi } \\
\text { Pengamatan }\end{array}$} & \multicolumn{2}{|c|}{ Konsentrasi Timbal } & \multirow{2}{*}{$\begin{array}{l}\text { Pb Tutut } \\
(\mathrm{mg} / \mathrm{kg})\end{array}$} & \multicolumn{2}{|c|}{ IFK } \\
\hline & $\begin{array}{c}\text { Pb Substrat } \\
(\mathrm{mg} / \mathrm{kg})\end{array}$ & $\mathrm{Pb}$ Air $(\mathrm{mg} / \mathrm{L})$ & & $\mathrm{IFK}_{0-\mathrm{s}}$ & $\mathrm{IFK}_{0-\mathrm{a}}$ \\
\hline Stasiun 1 & 5,09 & 0,0307 & 0,05 & 0,0099 & 1,6286 \\
\hline Stasiun 2 & 7,32 & 0,0307 & 0,05 & 0,0069 & 1,6286 \\
\hline Stasiun 3 & 3,26 & 0,0307 & 0,05 & 0,016 & 1,6286 \\
\hline Rata-rata & 5,2233 & 0,0307 & 0,05 & 0,0106 & 1,6286 \\
\hline
\end{tabular}


Hasil perhitungan nilai indeks faktor konsentrasi (IFK) tutut dalam substrat dan air termasuk kedalam kategori rendah. Hal ini sesuai dengan pernyataan Hutagalung (1990) yaitu besar atau kecilnya nilai IFK tergantung oleh lama pemaparan, serta kondisi lingkungan perairan. Berdasarkan kategori nilai IFK tersebut logam berat timbal $(\mathrm{Pb})$ di Waduk Cirata bersifat akumulatif rendah yaitu IFK $<100$.

\section{Parameter Fisik dan Kimiawi Perairan di Stasiun Penelitian}

Parameter fisik dan kimiawi yang diukur pada penelitian ini meliputi suhu, oksigen terlarut (DO), derajat keasaman $(\mathrm{pH})$. Hasil dari pengukuran parameter ini akan dibandingkan dengan baku mutu air yang telah ditetapkan oleh Peraturan Pemerintah No 82 Tahun 2001 Kelas I-IV tentang pengelolaan kualitas air dan pengendalian pencemaran air.

\section{Suhu}

Hasil pengukuran pada setiap stasiun penelitian, didapatkan nilai suhu berkisar antara $28,13^{\circ} \mathrm{C}-29,87^{\circ} \mathrm{C}$ (Gambar 5). Hal ini sesuai dengan baku mutu air menurut PP. RI No 82 Tahun 2001 yaitu $27^{\circ} \mathrm{C}-30^{\circ} \mathrm{C}$. Menurut Sumanto, (2019) suhu air yang optimum untuk kehidupan makrozoobentos adalah $20^{\circ} \mathrm{C}-30^{\circ} \mathrm{C}$. Suhu terendah terdapat pada stasiun 1 yang berada di wilayah Purwakarta daerah Tegal Datar, Maniis dengan suhu $28,13^{\circ} \mathrm{C}$. Rendahnya suhu pada stasiun 1 diakibatkan oleh waktu pengambilan data yang dilakukan pada pukul 09.50 WIB, suhu di stasiun 1 masih cocok untuk kehidupan tutut karena suhu di stasiun 1 masih berada dalam rentang $20^{\circ} \mathrm{C}$ $30^{\circ} \mathrm{C}$.

Suhu tertinggi pada stasiun 2 yang berada di wilayah Cianjur area Muara Sungai Cibalagung daerah Jangari yaitu $29,87{ }^{\circ} \mathrm{C}$. Hal tersebut dikarenakan pengukuran suhu dilakukan pada pukul 14.00 WIB. Lokasi stasiun 2 berada di wilayah yang memiliki banyak aktivitas karamba jaring apung sehingga banyak kapal-kapal nelayan yang melewati lokasi tersebut hal ini memberi pengaruh terhadap suhu perairan karena panas dari mesin kapal-kapal tersebut mempengaruhi suhu perairan. Tingginya suhu perairan disebabkan oleh tingginya intensitas cahaya, adanya pencampuran air dari sumber penyebab panas, serta faktor aktifitas yang ada pada lokasi tersebut. Kisaran suhu pada saat penelitian di stasiun 1, 2 dan 3 terdapat pada Gambar 5 .

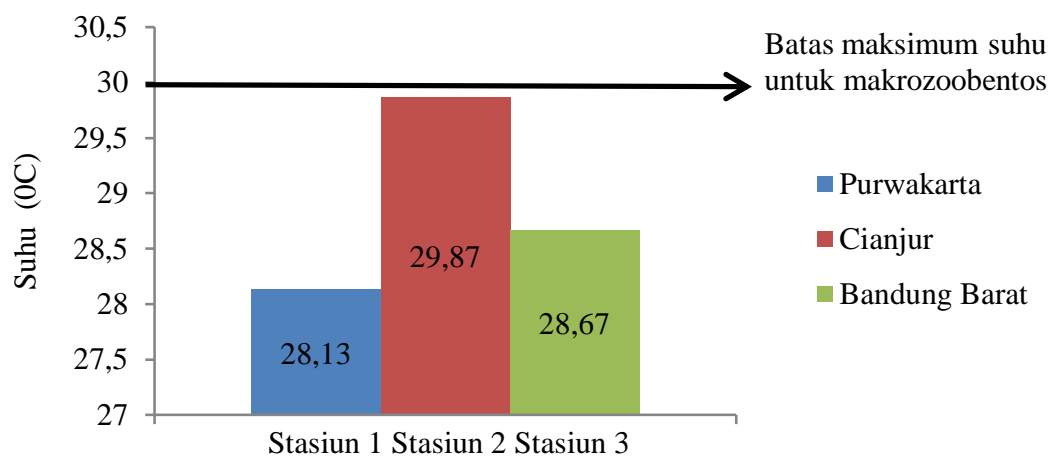

Gambar 5 Nilai suhu tertinggi yaitu stasiun 2 sedangkan nilai suhu terendah berada di stasiun 1 .

Suhu akan mempengaruhi kesetimbangan Logam $\mathrm{Pb}$ di dalam perairan yang tinggi maka senyawa logam berat timbal $(\mathrm{Pb})$ akan larut di air karena adanya penurunan laju absorpsi ke dalam partikulat. Absorpsi merupakan laju penyerapan yang dipengaruhi oleh faktor suhu. Pada biota perairan dengan suhu yang cenderung panas akan mempercepat laju metabolisme biota tersebut (Pratiwi, 2018)

\section{Oksigen Terlarut (DO)}

Pada penelitian ini DO (Oksigen terlarut) di ukur karena oksigen terlarut merupakan kebutuhan dasar untuk kehidupan hewan maupun tumbuhan di dalam air, Gastropoda memiliki kisaran toleransi lebar terhadap oksigen sehingga penyebaran dari gastropoda ini sangat luas. Konsentrasi oksigen terlarut di bawah $5 \mathrm{mg} / \mathrm{L}$ akan mengganggu fungsi dan kelangsungan hidup biota akuatik (Chapman \& Kimstach, 1992). Stasiun 1, 2 dan 3 mempunyai kisaran oksigen terlarut $2,27 \mathrm{mg} / \mathrm{L}-2,53 \mathrm{mg} / \mathrm{L}$ sehingga tidak layak untuk kehidupan tutut dan makrozoobenthos lainnya karena nilai oksigen terlarutnya rendah. Nilai DO terendah pada saat penelitian berada di stasiun 3, nilai DO tertinggi ada di stasiun 2 (Gambar 6). Banyak faktor yang mempengaruhi rendahnya nilai oksigen terlarut di stasiun penelitian, seperti banyaknya limbah industri atau limbah rumah tangga yang berasal dari sekitar stasiun penelitian. Hal ini akan mempengaruhi kelangsungan hidup dan perkembangan tutut.

Hasil pengukuran DO yang dilakukan selama pengamatan di tiga stasiun menunjukan bahwa DO di Waduk Cirata berkisar antara 2.27- $2.53 \mathrm{mg} / \mathrm{L}$ (Gambar 6). Nilai oksigen terlarut yang paling rendah berada di stasiun 3 sebesar 2,27 $\mathrm{mg} / \mathrm{L}$. Hal ini disebabkan keadaan stasiun 3 yang lebih banyak pemukiman wargasehingga banyak aktifitas rumah tangga yang menghasilkan limbah domestik di stasiun ini, selain itu ada karamba jaring apung dan aktifitas kapal yang membawa pakan ikan sehingga stasiun 3 menerima beban limbah yang lebih tinggi 
dibandingkan stasiun lainnya dan membutuhkan oksigen yang lebih banyak untuk mengurai limbah yang masuk ke perairan. Rendahnya nilai konsentrasi DO pada stasiun 3 dapat disebabkan karena pengaruh dari limbah domestik dari pemukiman warga, hal ini sesuai dengan pernyataan Yuliani (2015) yaitu deterjen yang meningkat akan berdampak negatif terhadap akumulasi surfaktan pada badan-badan perairan, sehingga menimbulkan masalah pendangkalan perairan, terhambatnya transfer oksigen. Selain dari limbah domestik faktor rendahnya nilai konsentrasi DO adalah dari banyaknya tanaman eceng gondok di stasiun 3. Peningkatan jumlah tanaman air akan menyebabkan peningkatan penguraian fosfat, dan penghambatan pertukaran oksigen dalam air, sehingga kadar oksigen terlarut dalam air sangat rendah (Handayani, 2020). Nilai oksigen terlarut tertinggi berada di stasiun 2 yaitu sebesar 2,53 $\mathrm{mg} / \mathrm{L}$. Warna air di lokasi penelitian stasiun 2 cenderung berwarna hijau, hal ini memungkinkan sedang terjadinya proses fotosintesis. Konsentrasi DO berfluktuasi secara harian dan musiman, tergantung pada pencampuran dan pergerakan massa air, aktifitas fotosintesis, respirasi dan limbah yang masuk ke perairan (Effendi, 2003). Berdasarkan nilai baku mutu air PP. RI No 82 Tahun 2001 untuk oksigen terlarut kelas III sebesar $>3 \mathrm{mg} / \mathrm{L}$ dan kelas IV sebesar $>0 \mathrm{mg} / \mathrm{L}$, maka dapat disimpulkan bahwa konsentrasi DO di Waduk Cirata tidak memenuhi baku mutu kelas III.

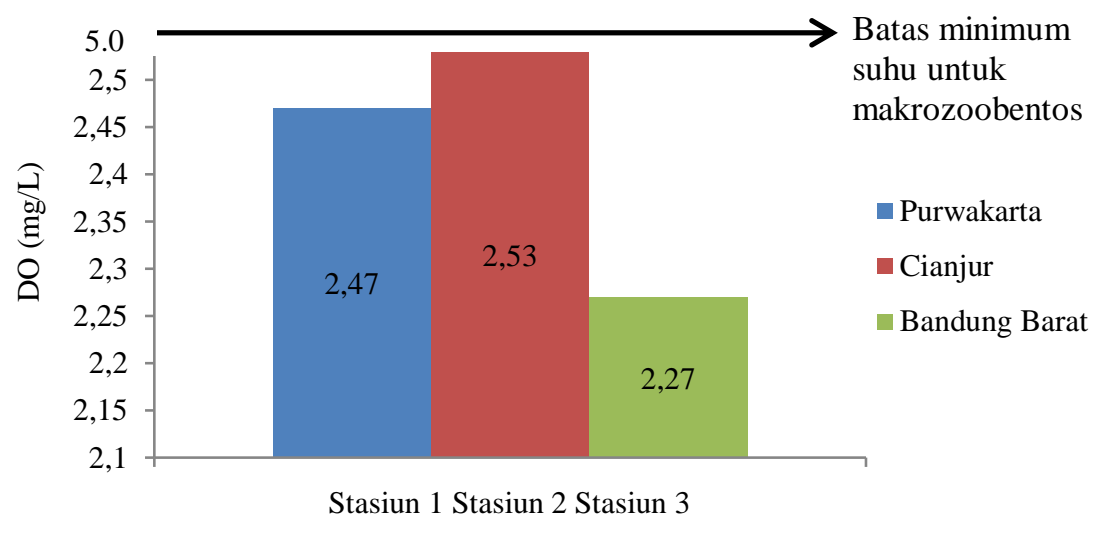

Gambar 6 Nilai DO pada saat penelitian di tiap stasiun berkisar antara 2,27-2,53 mg/L.

\section{Derajat Keasaman (pH)}

Nilai $\mathrm{pH}$ yang didapatkan pada hasil pengukuran di Waduk Cirata berkisar antara 7,15 7,55. Nilai kisaran tersebut sesuai baku mutu air menurut PP. RI No 82 Tahun 2001 yang menetapkan derajat keasaman $(\mathrm{pH})$ antara $6-9$. Nilai $\mathrm{pH}$ terendah yaitu 7,15 pada stasiun 3 yang dipengaruhi oleh adanya limbah organik seperti aktivitas penduduk, banyaknya eceng gondok dan adanya aktifitas lalu lintas kapal sehingga terjadi perombakan bahan organik yang menghasilkan asam organik. Sedangkan nilai $\mathrm{pH}$ tertinggi terdapat di stasiun 2 yaitu sebesar 7,55 hal ini kemungkinan diakibatkan karena karakteristik dari stasiun ini yang warna airnya dominan hijau sehingga kemungkinan sedang terjadi fotosintesis. Peristiwa fotosintesis membutuhkan banyak ion $\mathrm{CO}_{2}$ sehingga mengakibatkan $\mathrm{pH}$ air naik. Nilai pH pada saat penelitian berkisar antara7,15 7,55, dan $\mathrm{pH}$ terendah berada di stasiun 3 sedangkan $\mathrm{pH}$ tertinggi berada di stasiun 2 (Gambar 7).

Nilai $\mathrm{pH}$ pada ketiga stasiun penelitian menunjukan kondisi perairan yang baik untuk habitat tutut (Gambar 7). Hal ini sesuai dengan pernyataan Hynes (1978) yang mengemukakan hewan gastropoda air tawar umumnya dapat hidup secara optimal pada lingkungan dengan kisaran $\mathrm{pH}$ 5,0-9,0. Ini artinya bahwa, perairan Waduk Cirata yang mempunyai $\mathrm{pH}$ berkisar antara 7,15 - 7,55, termasuk habitat ini masih sangat baik untuk menjadi tempat perkembangbiakan dari gastropoda.

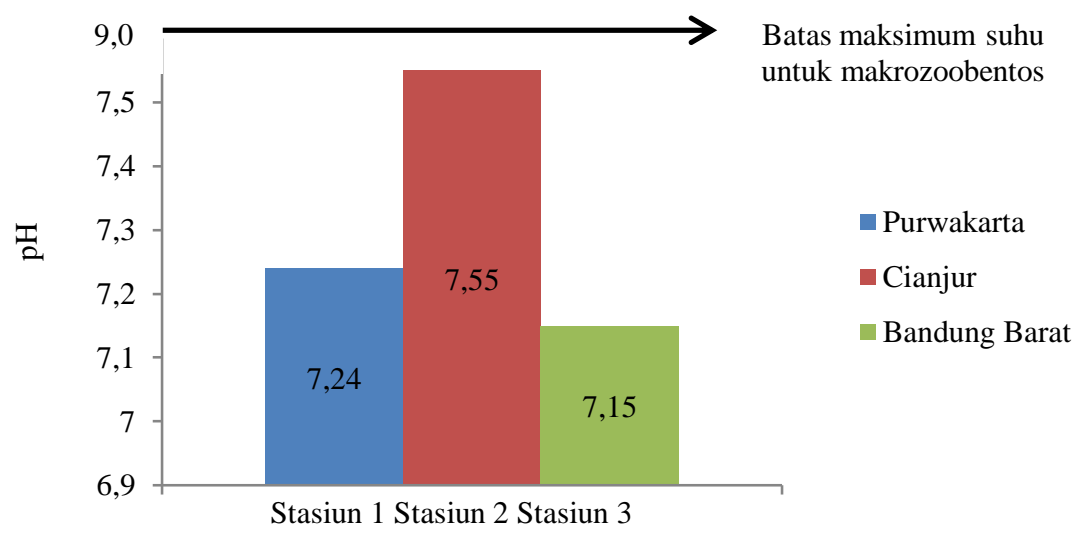

Gambar 7 Kisaran pH pada saat penelitian sebesar 7,15 - 7,55. 


\section{SIMPULAN}

Kandungan logam berat timbal $(\mathrm{Pb})$ pada air di Waduk Cirata dari 3 stasiun pengamatan sudah melebihi baku mutu yang ditetapkan oleh Peraturan Pemerintah No. 82 Tahun 2001. Kandungan logam berat timbal $(\mathrm{Pb})$ pada substrat di Waduk Cirata dari 3 stasiun pengamatan tergolong rendah berdasarkan IACD/CEDA (1999). Kandungan logam berat timbal $(\mathrm{Pb})$ pada tutut di Waduk Cirata dari 3 stasiun pengamatan yaitu masih layak dikonsumsi sesuai dengan SNI No. 7387 Tahun 2009. Nilai indeks faktor konsentrasi tutut terhadap substrat dan nilai indeks faktor konsentrasi tutut terhadap air bersifat akumulatif rendah. Sumber cemaran logam berat timbal $(\mathrm{Pb})$ di Waduk Cirata ini bersumber dari buangan limbah industri, domestik dan pertanian yang berada di sekitar Waduk Cirata.

\section{DAFTAR PUSTAKA}

Chapman D \& Kimstach V. (1992). Selection of Water Quality Variables. in. Chapman D (Ed.). Water Assessment. UNESCO: WHO and UNEP.

Connell D \& Miller G. (1996). Chemistry and Ecotoxicology of Pollution. Jakarta: Universitas Indonesia Press.

Darmono (1995). Logam dalam Sistem Biologi Makhluk Hidup. Jakarta: Universitas Indonesia Press.

Dhahiyat Y. (2011). Ekologi Perairan. Bandung: Unpad Press.

Effendi H. (2003). Telaah Kualitas Air bagi Pengelolaan Sumberdaya dan Lingkungan Perairan. Yogyakarta: Kanisius.

Handayani L. (2020). Pengaruh Kandungan Deterjen pada Limbah Rumah Tangga terhadap Kelangsungan Hidup Udang Galah (Macrobacium rosenbergii). Sebatik, 24, (1), 75-80.

Hidayah A, Purwanto \& Soeprobowati T. (2012). 2012. Kandungan Logam Berat pada Air, Sedimen dan Ikan Nila (Oreochromis niloticus Linn.) di Karamba Danau Rawapening. Seminar Nasional Pengelolaan Sumberdaya Alam dan Lingkungan. Semarang.

Hidayah A, Purwanto P \& Soeprobowati T. (2014). Biokonsentrasi Faktor Logam Berat $\mathrm{Pb}, \mathrm{Cd}$, $\mathrm{Cr}$ dan $\mathrm{Cu}$ pada Ikan Nila (Oreochromis niloticus Linn.) di Karamba Danau Rawa Pening. Bioma : Berkala Ilmiah Biologi, 16, (1), 1-9.

Hutagaol S. (2012). Kajian Kandungan Logam Berat Timbal $(\mathrm{Pb})$ pada Air, Sedimen dan Kerang Hijau (Perna viridis, Linn.) di Perairan Muara Kamal, Provinsi DKI Jakarta. Skripsi. Institut Pertanian Bogor.

Hutagalung H. (1990). Pencemaran Laut oleh Logam Berat. Status Pencemaran Laut Indonesia dan Teknik Pemecahannya. Jakarta: P3OLIPI.
Hutagalung H. (1991). Pencemaran Laut Oleh Logam Berat. dalam Status. Pencemaran Laut di Indonesia dan Teknik Pemantauannya. Jakarta: P30- LIPI.

Hynes H. (1978). The Biology of Polluted Waters. London: Liverpool University press.

[IACD/CEDA] International Association of Draging. Companies/Central Dreging Association, 1999. Convension, Codes and Conditions : Marine Disposal. Enviromental Aspect of Dredging.

Nurcahya Y \& Nugraha Y. (2014). Komposisi dan Kelimpahan Fitoplankton di Waduk Cirata, Jawa Barat. Buletin Teknik Litkayasa, 12, (1), 37-43.

Nurhayati D \& Putri D. (2019). Bioakumulasi Logam Berat pada Kerang Hijau (Perna viridis) di Perairan Cirebon Beradasarkan Musim yang Berbeda. Jurnal Akuatika Indonesia, 4, (1), 610.

Irhamni, Pandia S, Purba E \& Hasan W. (2017). Serapan Logam Berat Esensial dan Non Esensial pada Air Lindi TPA Kota Banda Aceh dalam Mewujudkan Pembangunan Berkelanjutan. Serambi Engineering, 2, (3), 134-140.

Johnston R. (1976). Mechanisms and problem of marine pollution in relation to commercial fisheries. London: Academic Press.

Oktavianus \& Salami I. (2005). Uptake dan Depurasi Logam Timbal $(\mathrm{Pb})$ pada Ikan Nila (Oreochromis niloticus). Jurnal Kimia Lingkungan, 6, (2), 75-81.

Pemerintah Indonesia. (2001). Peraturan Pemerintah Republik Indonesia Nomor 82 Tahun 2001 Tentang Pengelolaan Kualitas Air dan Pengendalian Pencemaran Air. Jakarta: Sekretariat Negara.

Pratiwi ST. (2018). Tingkat Pencemaran Logam Berat Timbal (Pb) Pada Kepiting Bakau (Scylla spp.) di Hutan Mangrove Mura Bendera Kecamatan Muara Gembong, Jawa Barat. Skripsi. Universitas Padjadjaran.

Prasiwi I, Wardhani E \& Qonita F. (2017). Analisis Kualitas Air Waduk Cirata Provinsi Jawa Barat. Seminar Nasional Bidang Teknik Lingkungan: Rekasaya dan Manajemen Lingkungan Berkelanjutan II. Bandung: Institut Teknologi Nasional.

Priyanto N, Dwiyitno D \& Ariyani F. (2008). Kandungan Logam Berat $(\mathrm{Hg}, \mathrm{Pb}, \mathrm{Cd}$, dan $\mathrm{Cu}$ ) Pada Ikan, Air, dan Sedimen di Waduk Cirata, Jawa Barat. Jurnal Pascapanen Dan Bioteknologi Kelautan Dan Perikanan, 3, (1), 69-78.

Rochyatun E, Kaisupy M \& Rozak A. (2006). Distribusi Logam Berat Dalam Air dan Sedimen di Perairan Kamal Muara, Jakarta Utara. Skripsi. Institut Pertanian Bogor.

Saputra A. (2009). Pengamatan Logam Berat pada Sedimen Perairan Waduk Cirata.Media Akuakultur, 4, (1), 84-88. 
Sumanto N. (2019). Keanekaragaman Makrozoobentos di Sungai Bah Bolon Kabupaten Simalungun Sumatera Utara. Bioscientist : Jurnal Ilmiah Biologi, 7, (1), 8-15.

van Esch G. (1977). Aquatic pollutant and their potential ecological effects. In Hutzingen o., I.H. Van Lelyuccid and B.C.J. Zoetemen, ed. Aquatic pollution : Transformation and Biological Effects. New York: Pergamon Press.
Wicaksono E, Sriati \& Lili W. (2016). Sebaran Logam Berat Timbal $(\mathrm{Pb})$ pada Makrozoobenthos di Perairan Waduk Cirata, Provinsi Jawa Barat. Jurnal Perikanan Kelautan, 7, (1), 103114.

Yuliani RL. (2015). Pengaruh Limbah Deterjen Industri Laundry Terhadap Mortalitas Dan Indeks Fisiologi Ikan Nila (Oreochromis niloticus). Seminar Nasional XII Pendidikan Biologi FKIP. Surabaya: UNS, 822 -28. 